\title{
Preliminary research for identification of bacteria useful in microbially induced calcium carbonate precipitation
}

\author{
Katarzyna Misiołek ${ }^{1, *}$, Pawet Popielski ${ }^{1}$, and Katarzyna Affek ${ }^{2}$ \\ ${ }^{1}$ Department of Hydro-Engineering and Hydraulics, Faculty of Building Services, Hydro and \\ Environmental Engineering, Nowowiejska 20, 00-653 Warsaw, Poland \\ ${ }^{2}$ Department of Biology, Faculty of Building Services, Hydro and Environmental Engineering, \\ Nowowiejska 20, 00-653 Warsaw, Poland
}

\begin{abstract}
MICP (Microbially Induced Calcite Precipitation) is a new biological method in soil stabilization. This cheap and eco-friendly technique improves strength parameters of the ground such as shear strength and decreases the permeability of gravelly and sandy soil. There are variety of microorganisms that can be used in calcite precipitation. The most popular method is precipitation of calcium carbonate by bacteria. The main purpose of the article is to present the results from Gram staining of bacteria isolated from construction sites, which is the first step of their identification. Gram's method allows to find out which morphological groups of bacteria are adapted to conditions present in soil from construction sites and therefore are potentially able to produce calcite. The article describes the methodology of isolation, staining and determination of morphological types of bacteria.
\end{abstract}

\section{Introduction}

Soil stabilization is one of the main tasks in geotechnics. Dikes, slopes become often unstable and are susceptible to erosion. Excavations during constructions have to be always secured against landslides. Soil stabilization is very desirable for many aspects of the engineering.

There are plenty of methods to achieve soil stabilization at the surface such as compaction, adding nails or sheets in a slope or mixing soil with lime or cement [1]. There are also some more ecological methods like planting trees, grass or bushes $[2,3]$. Steening the excavations require more sophisticated and strengthening techniques like soldier beams, sheet piling, slurry wall, soil mixing or bracing. However, as the zone of influence of these techniques is limited to the closeness of the mixing area or short hardening time of the injected grouts, these traditional methods are not suitable for large volumes [4].

Popular techniques such as cement grouting are expensive, environmentally harmful and require heavy machinery. Fortunately, research is carried out to find the potential of biological techniques for ground reinforcement (stabilization) [5-7].

\footnotetext{
* Corresponding author: katarzyna misiolek@is.pw.edu.pl
} 
Microbial carbonate precipitation (MCP) has experienced an increased level of interest every year [6]. From geotechnical perspective, the application of MCP has become more and more popular in improvement techniques.

For research purposes wide literature studies were performed. Urease active bacteria are studied for MICP (Microbially Induced Calcite Precipitation) purpose from the eighties of the twentieth century [15]. The MICP process is recognized as promising in comparison to previous conventional methods and many sources confirmed it is effective, causes an increase in the shear stress parameter and decrease in the permeability parameters in gravel and sandy soils [7].

According to the literature MICP process can be used in many aspects of the civil engineering. Application of bacteria into concrete during the mixing process is one of it. The strength improvements obtained by mixing bacteria into concrete shows variable results. On one side it has been proven that concrete-bacteria samples increases compressive strength with 9 to $15 \%$ after 28 days. Although on the other side some literature sources mention both positive and negative effects. It depends on type of bacteria, its concentration or concrete age.

Another option of using MICP is crack remediation in concrete and limestone. Researchers made the biodeposition treatment on the Maastricht limestone surface. They were able to achieve homogeneously strengthened limestone up to depths of $30 \mathrm{~mm}$ after two spray applications during the same day. It is possible to lower the cost of the method by optimizing the concentration of urease and carbonate. However, calcium carbonate is hygroscopic, which triggers high probability of damage in the stone [8].

Soil stabilization is another way of using MICP method. Whiffin et al. examined the effect of microbial carbonate precipitation on sandy soil, especially its parameters such as permeability and shear strength. 5-meter column of soil, which simulated field condition, was filtered by microbially treatment. The triaxial tests revealed that the strength, soil porosity and stiffness were significantly affected by the MICP treatment [6].

Another very important aspects of the MICP method is optimizing the key parameters such as chemical and biological composition, flow rates and flow direction. Researchers monitored the chemical, biological and physical properties important for the MICP method. It has been proved that $\mathrm{pH}$, dissolved inorganic carbon concentrations, calcium concentration and availability of nucleation sites (which means the type of bacteria) have significant influence on biocementation [6].

Type of bacteria is essential in MICP. Microorganisms are responsible for production of urease, they provide nucleation sites and generate an alkaline environment through different physiological actions [9]. The most efficient type of bacteria come from Bacillus group and will be wider described further.

The general purpose of the research is to isolate bacterial consortium which will precipitate carbonate efficiently enough to be used in ground stabilization. The article describes the preliminary identification of morphological groups of urease active bacteria by Gram staining. Before application in MICP selected bacterial cultures will be identified also biochemically and molecularly. 


\section{MICP - microbially induced calcium carbonate precipitation}

Microbial carbonate precipitation is a new environmental friendly method in increasing the strength of the ground. Microbially induced calcium carbonate precipitation (MICP) in environmental engineering has been studied mainly for crack remediation in concrete, soil improvement and application in the fields of surface protection of natural stone [8]. MICP as a new technique in engineering is better than conventional chemical methods, which are environmentally harmful, often toxic and expensive [1,7]. Many resources in literature have confirmed that MICP method is very effective in increasing the strength parameters in the ground such as shear strength and decreasing the permeability of gravelly and sandy soil [9-11].

The calcium carbonate precipitation is a simple process and easily induce high concentration of $\mathrm{CaCO}_{3}$ in relatively short period of time [12].

Urease catalyzes the hydrolysis of urea into ammonium and carbonate. In this reaction, one mole of urea is hydrolyzed to one mole of carbamic acid (1), which is hydrolyzed to another one mole of ammonia and carbonic acid (2) [13-15].

$$
\begin{aligned}
& \mathrm{CO}\left(\mathrm{NH}_{2}\right)_{2}+\mathrm{H}_{2} \mathrm{O} \rightarrow \mathrm{NH}_{2} \mathrm{COOH}+\mathrm{NH}_{3} \\
& \mathrm{NH}_{2} \mathrm{COOH}+\mathrm{H}_{2} \mathrm{O} \rightarrow \mathrm{NH}_{3}+\mathrm{H}_{2} \mathrm{CO}_{3}
\end{aligned}
$$

Those two products $\left(\mathrm{NH}_{3}\right.$ and $\left.\mathrm{H}_{2} \mathrm{CO}_{3}\right)$ are further equilibrated in water to form bicarbonate (3), two moles of ammonium and two moles of hydroxide ions (4).

$$
\begin{aligned}
& \mathrm{H}_{2} \mathrm{CO}_{3} \leftrightarrow \mathrm{HCO}_{3}^{-}+\mathrm{H}^{+} \\
& 2 \mathrm{NH}_{3}+2 \mathrm{H}_{2} \mathrm{O} \leftrightarrow 2 \mathrm{NH}_{4}^{+}+2 \mathrm{OH}^{-}
\end{aligned}
$$

The hydroxide ions result in an increase of $\mathrm{pH}$, which can shift the bicarbonate equilibrium, and, in result, lead to carbonate ions formation (5) [16].

$$
\mathrm{HCO}_{3}^{-}+\mathrm{H}^{+}+2 \mathrm{OH}^{-} \leftrightarrow \mathrm{CO}_{3}^{2-}+2 \mathrm{H}_{2} \mathrm{O}
$$

$\mathrm{CaCO}_{3}$ precipitation occurs at the bacterial cell surface if there are sufficient concentrations of $\mathrm{Ca}^{2+}$ and $\mathrm{CO}_{3}^{2-}$ in ambient medium $(6,7)$ [17].

$$
\begin{aligned}
& \mathrm{Ca}^{2+}+\text { Bacterial cell } \rightarrow \text { Cell }-\mathrm{Ca}^{2+} \\
& \text { Cell }-\mathrm{Ca}^{2+} \mathrm{CO}_{3}^{2-} \rightarrow \mathrm{Cell}-\mathrm{CaCO}_{3}
\end{aligned}
$$

Urease active bacteria are very important in $\mathrm{CaCO}_{3}$ precipitation, because the microorganisms provide nucleation sites and influence the types of minerals formed $[18,19]$.

\section{Isolation of ureolytic bacteria}

The main purpose of the research was to find the microorganisms that produce high level of urease and calcite precipitation. There are many sources in natural environment from which it is possible to isolate necessary bacteria, such as mules, settlement, ground. Around fifteen samples of soil were collected from different sources, mainly from 1-2 m deep excavations (near construction sites) in Warsaw and Mińsk Mazowiecki, Poland (Fig.1.). Samples were 
collected to the sterile containers, about $100 \mathrm{~g}$ each. Then containers were kept under refrigeration conditions $\left(8^{\circ} \mathrm{C}\right)$.

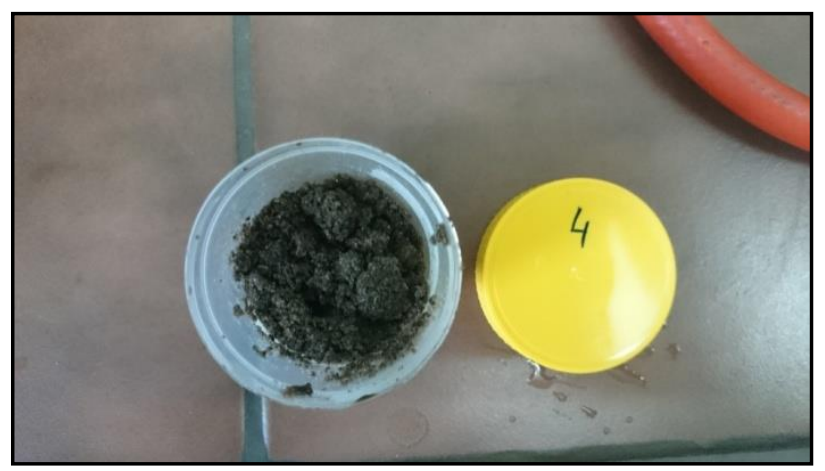

Fig. 1. Exemplary sample of ground.

\subsection{Ureolytic bacteria}

Bacterial suspensions were obtained by shaking the sample of soil $(10 \mathrm{~g})$ with sterile water $(90 \mathrm{ml})$ for $0.5 \mathrm{~h}$. Afterwards spread plate method was carried out (Enriched LAB-AGAR, incubation time $24 \mathrm{~h}$ in temperature $37^{\circ} \mathrm{C}$ ).

Isolation of bacteria from each sample was made by streak plate method. Streak plate method is a qualitative technique suitable for isolation of a pure strain of bacteria from environmental sample. Then samples were taken from the resulting colonies and a bacterial culture grew on a new agar plate for $24 \mathrm{~h}$ in temperature $37^{\circ} \mathrm{C}$ [20].

The next step of the study was determination of bacteria with urease activity on Christensen's urea broth (BTL PL Company) $\left(24 \mathrm{~h}, 37^{\circ} \mathrm{C}\right)$. Urease producing bacteria changed the Christensen's urea broth's (BTL PL Company) colour into pink (Fig.2.).

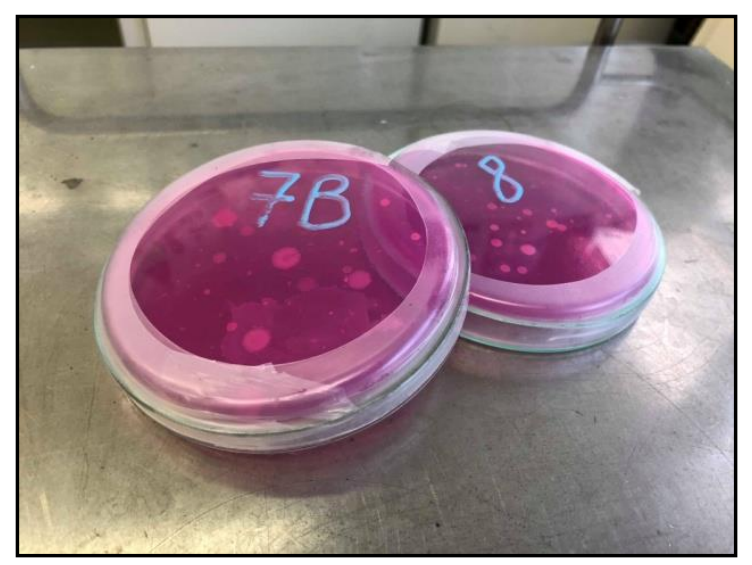

Fig. 2. Bacterial colonies on Christensen's urea broth (BTL PLCompany).

Afterwards, to check if obtained microorganisms producing urease are able to grow also in cooler conditions, they were incubated in $20^{\circ} \mathrm{C}$ and $26^{\circ} \mathrm{C}$ for 24 and $48 \mathrm{~h}$.

Only bacterial samples producing urease after $24 \mathrm{~h}$ of incubation in all tested temperatures were stained by Gram's method. During the research 16 such bacterial strains were obtained. 


\section{Gram's method in preliminary bacterial identification}

Gram staining method was developed by Danish physician Hans Christian Gram in 1884 [21]. The method is one of the most popular procedure in microbiology and constitutes the very first step of bacterial identification. It is used to classify bacterial species into two large groups: Gram-positive and Gram-negative, which differ in the structure of the cell walls, but is also used to visualize a morphological group of bacteria. After staining Gram-positive cells become purple while Gram-negative are pink. The procedure of Gram staining method is quick, easy and cheap. The whole staining procedure is well known and widely described in literature [21-22].

Gram-positive bacteria were stained purple with a longer and wider shape than Gramnegative bacteria. During the observation seven Gram-positive colonies, four Gram-negative bacteria and five undefined were found. Undefined bacteria were longer and thicker in shape than Gram-negative, sometimes forming chains which is typical for Gram-positive bacteria. The probable cause of the occurrence of these transitional forms is related to soil contamination. All presented bacterial strains produced some level of urease. Further research will show which of those bacteria are able to produce the highest amount of enzyme, which will also predestine them to precipitate calcite effectively.

Below some of the obtained bacterial morphological forms are shown (Fig.3.-Fig.8).
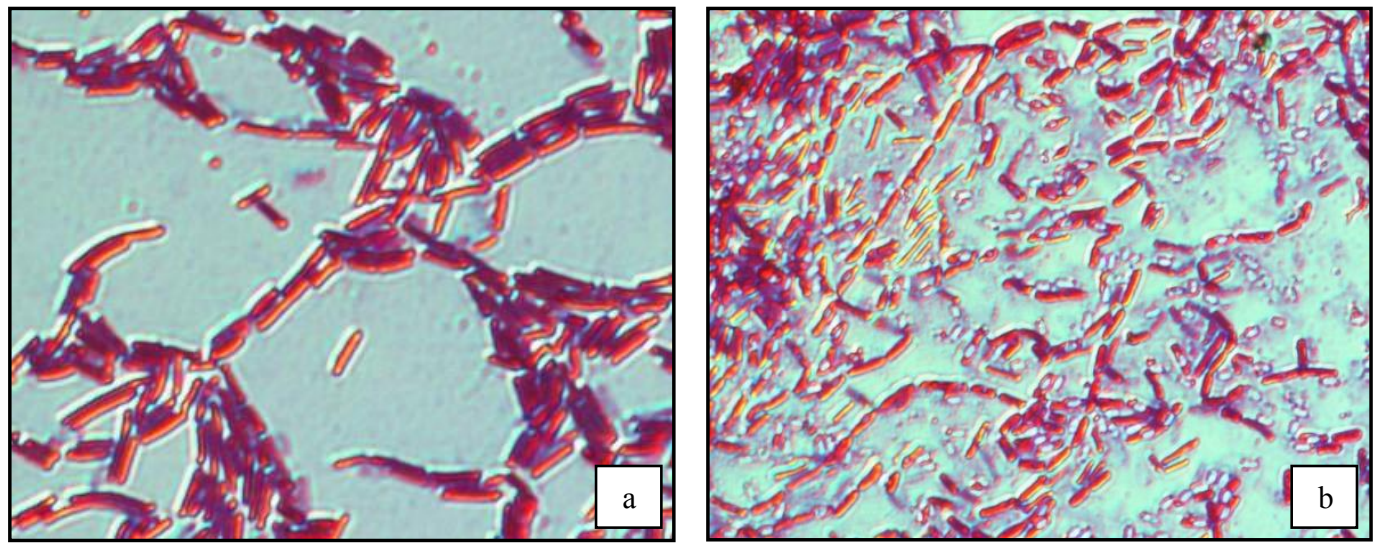

Fig. 3. (a) Colonies A, Gram-positive bacteria (purple colour), (b) Colonies B, Gram-positive bacteria (purple colour).
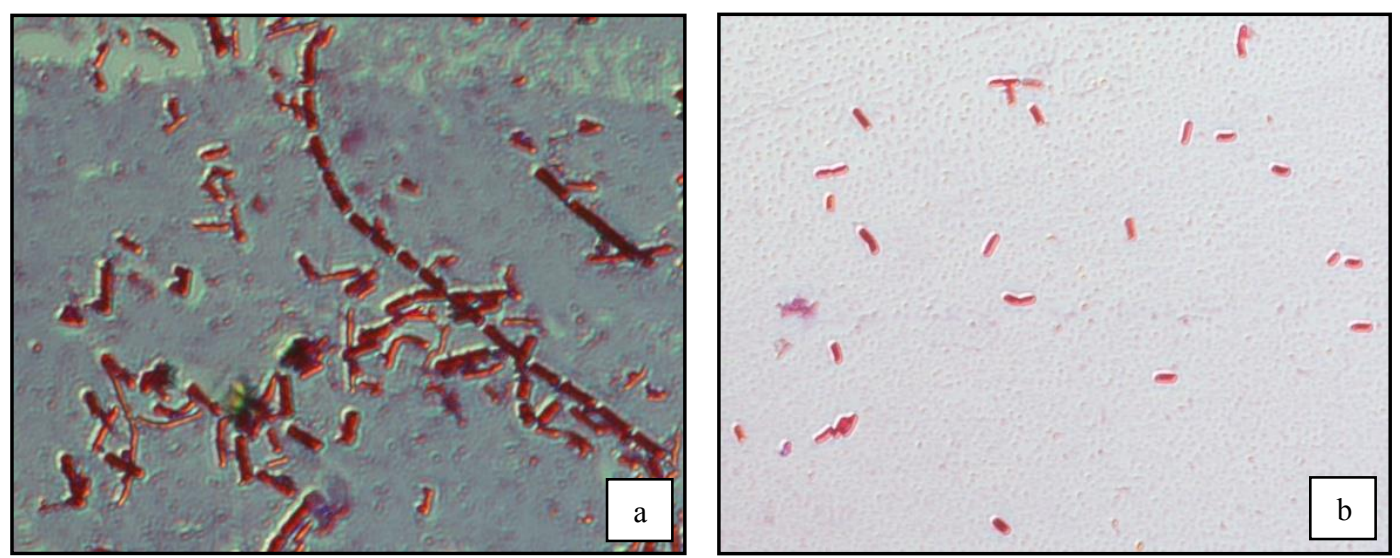

Fig. 4. (a) Colonies C, Gram-positive bacteria (purple colour), (b) Colonies D, Gram-negative bacteria (pink colour). 


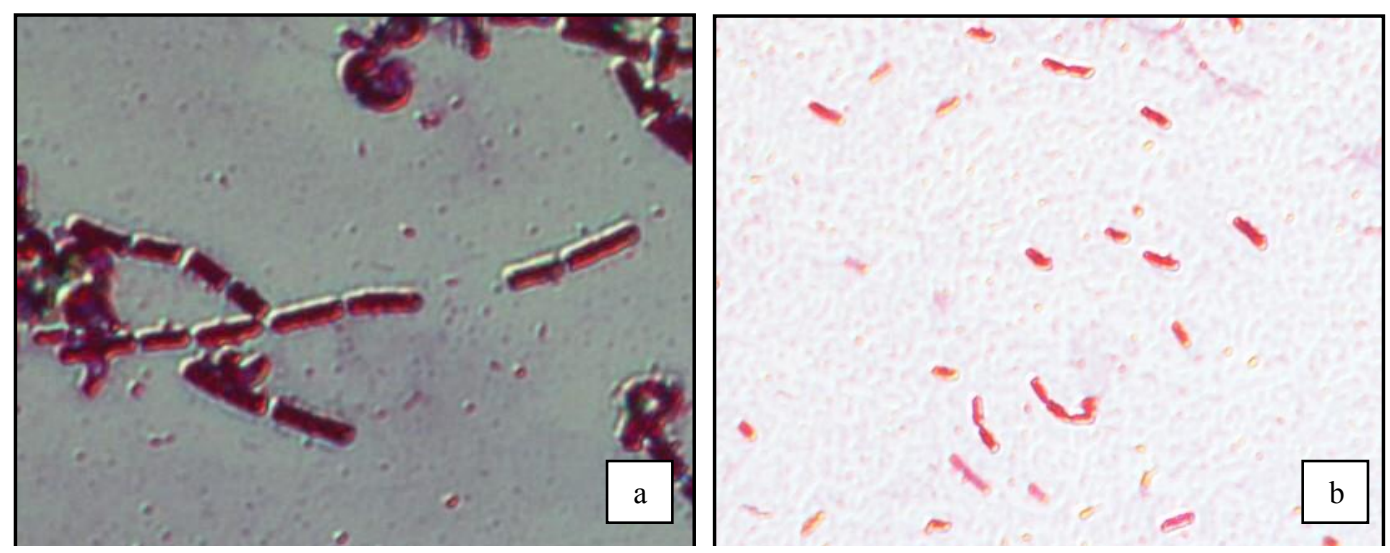

Fig. 5. (a) Colonies E, Gram-positive bacteria (purple colour), (b) Colonies F, undefined bacteria.
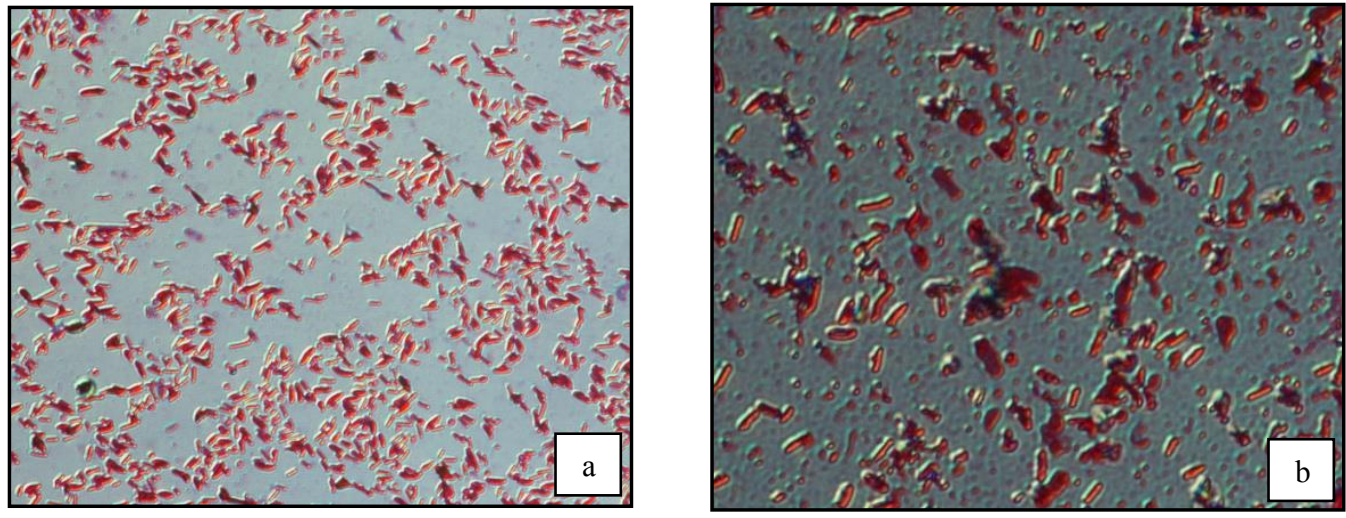

Fig. 6. (a) Colonies G, Gram-negative bacteria (pink colour), (b) Colonies H, undefined bacteria.
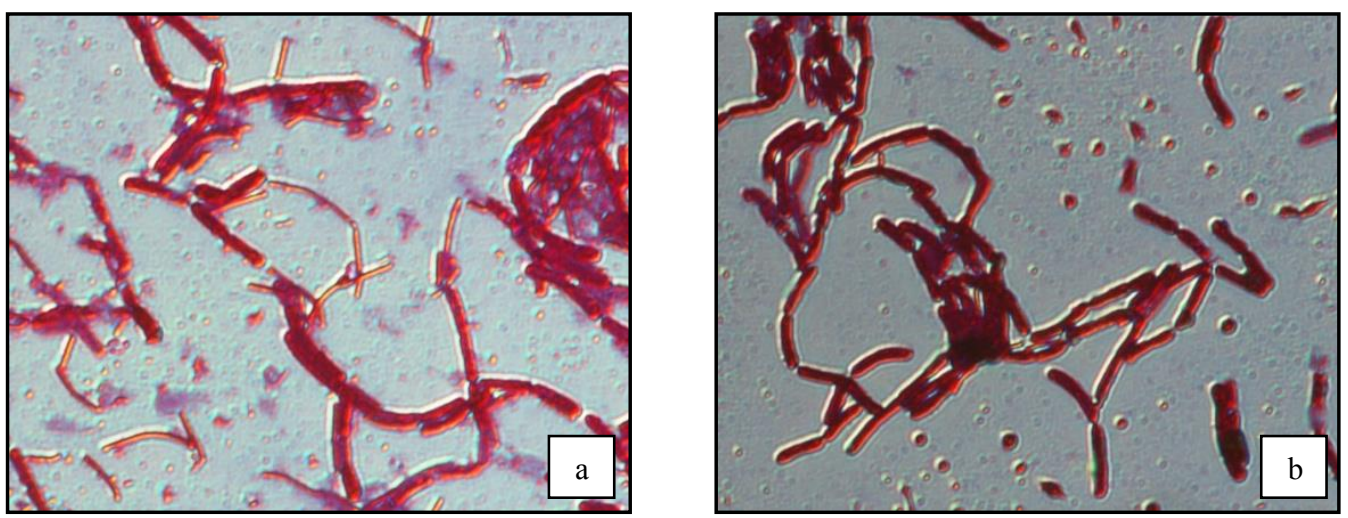

Fig. 7. (a) Colonies I, Gram-positive bacteria (purple colour), (b) Colonies J, Gram-positive bacteria (purple colour). 

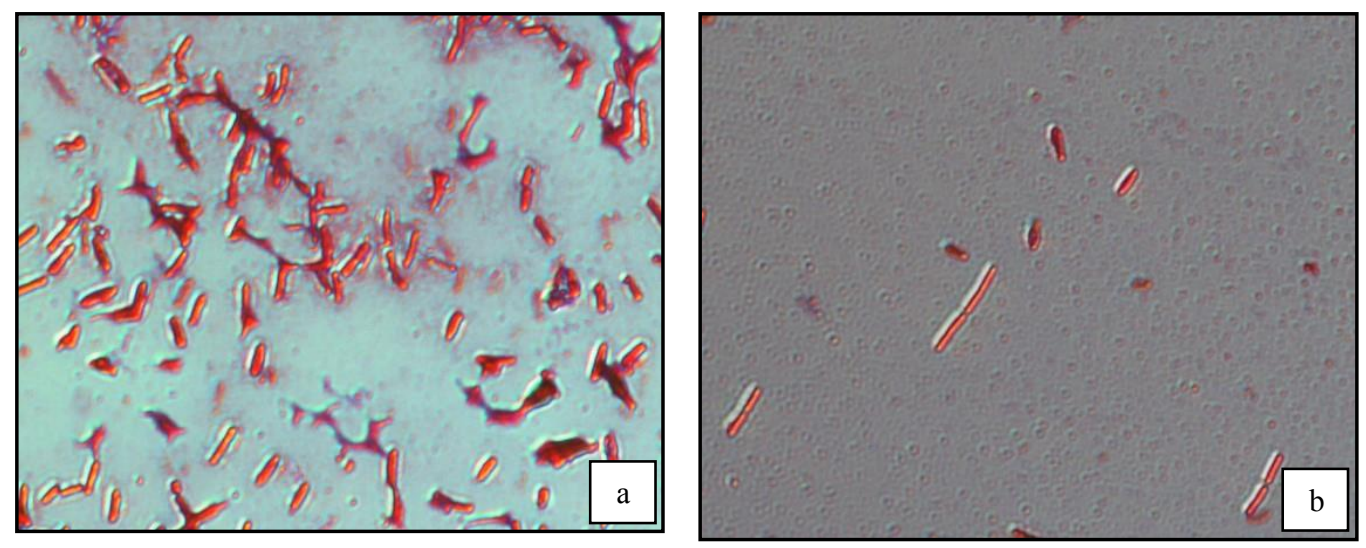

Fig. 8. (a) Colonies K, undefined bacteria, (b) Colonies L, undefined bacteria.

\subsection{Bacteria type}

One of the most essential factors in efficiency of MICP is the type of bacteria carrying out the process. During the research there were found different morphological types of bacteria which are able to produce various amounts of urease. According to the literature, Bacillus pasteurii (also known as Sporosarcina pasteurii), which produces a high level of urease, plays an important role in MICP [23-25]. This type of bacteria was used in many studies for biocementation induction in the soil like sand or gravel [26-27].

Species of the genus Bacillus such as Bacillus pateurii are typical Gram-positive bacteria. During the study in seven samples of soil Gram-positive bacilli were found. The research conducted in this work is preliminary to larger studies in which the next step will answer the question whether isolated urease active bacteria are able to carry out the process of soil biocementation. Afterwards more detailed identification of microorganisms (biochemical and molecular) will be performed.

\section{Conclusions}

During the laboratory research the seven samples of soil Gram-positive bacilli were found. The further tests will show which of them are able to induce soil stabilization. MICP is a relatively new method in increasing the strength of soil parameters as well as cement sealing in concrete and is considered as eco-friendly and cost-effective comparing to the conventional techniques using cement or limestone [28]. This aspects of the microbiological process should encourage geotechnical engineers to use MICP method in the future. However, MICP technology has still many uncertainties, which have to be solved by further research to eliminate any difficulties and limitations. The future studies will concentrate on selection of accurate parameters to obtain the best results of biocementation.

\section{References}

1. R.H. Karol, Chem. Gr. and Soil Stab., 558, (New York, 2003)

2. J. Widdows, M. Brinsley, J. of Sea Res. 48(2), 143-156 (2002)

3. C. C. Fan, C. F. Su, Ecol. Eng. 33(2), 157-166 (2008) 
4. L.A. van Paassen, M.P. Harkes, G.A. van Zwieten, W.H. van der Zon, W.R.L. van der Star, M.C.M. van Loosdrecht, $17^{\text {th }}$ Int. Conf. On Soil ech. and Geot. Eng., 2328, (2009)

5. J.T. DeJong, M.B. Fritzges, K. Nusslein, J. of Geot. and Geoenv. Eng. 132(11), 1381-1392 (2006)

6. V.S. Whiffin, L.A. van Paassen, M.P. Harkes, Geomic. J. 24(5), 417-423 (2007)

7. V. Ivanov, J. Chu, Rev. in Env. Sc. and Biot. 7(2), 139-153 (2008)

8. N. De Belie, RILEM Tech. Let. 1, 56-61(2016)

9. L.A. Van Paassen, Ghose, Ranajit, T.J.M. Van der Linden, W.R.L. Van der Star, M.C.M. Van Loosdrecht, J. Geotech. Geoenviron. Eng. 136(12), 1721-1728 (2010)

10. W.K. Van Wijngaarden, F.J. Vermolen, G.A.M Van Meurs, C. Vuik, Trans. Porous Med. http://dxdoi.org/10.1007/s11242-010-9691-8 (2010)

11. W.R.L. Van der Star, W.K. Van Wijngaarden, L.A. Van Paassen, L.R. Van Baalen, G. Van Zwieten, Stab. of Gravel Dep. Using Microorg., 85-90 (2011)

12. N.K. Dhami, M.S. Reddy, A. Mukherjee, Front. Microbiol. 4, 1-13 (2013)

13. S. Stocks-Fischer, J.K. Galinat, S.S. Bang, Soil Biol Biochem 31, 1563-1571 (1999)

14. R.A. Burne, Y.Y. Chen, Microbes Infect 2, 533-542 (2000)

15. F. Hammes, N. Boon, J. de Villiers, W. Verstraete, S.D. Siciliano, Appl. Environ. Microniol 69, 4901-4909 (2003)

16. Y. Fujita, J. Taylor, T. Gresham, M. Delwiche, F Colwell, T. McLing, L. Petzke, R. Smith, Environ. Sci. Technol. 42, 3025-3032 (2008)

17. C. Qian, R. Wang, L. Cheng, J. Wang, Chin. J. Chem., 28, 847-857 (2010)

18. S. Douglas, T.J. Beveridge, FEMS Microbiol Ecol, 26, 79-88 (1998)

19. C. Rodriquez-Navarro, F. Jroundi, M. Schiro, E. Ruiz-Agudo, M.T. Gonzalez-Munoz, Appl Environ Microbiol 78, 4017-4029 (2012)

20. https://en.wikipedia.org/wiki/Streaking_(microbiology)

21. J.W. Bartholomew, T. Mittwer, Bacterial Rev. 16(1), 1-29 (1952)

22. C. Gram, Fortschr. Med., 2, 185-189 (1884)

23. S.S. Bang, J.K. Galinat, V. Ramakrishnan, Enzym. Microb. Technol. 28, 404-409 (2001)

24. J.T. Dejong, B.M. Mortenes, B.C. Martinez, D.C. Nelson, Ecol. Eng. 36(2), 197-210 (2010)

25. A.C. Mitchell, F.G. Ferris, Geomicrobiol. J. 23, 213-226 (2006)

26. K.L. Bachmeier, A.E. Williams, J.R. Warmington, S.S. Bang, J. Biotechnol. 93, 171-181 (2002)

27. D. Sarda, S. Choonia, D.D. Sarode, S.S. Lele, J. Ind. Microbiol. Biotechnol. 36, 1111-1115 (2009)

28. A. Periasamy, K. Ho-Chang, S. Yu-Jin, S. Jae-Seong, Springer Open Access (2016) 